\title{
Continental-scale assessment of provisioning soil functions in Europe
}

\author{
Gergely Tóth*, Ciro Gardi, Katalin Bódis, Éva Ivits, Ece Aksoy, Arwyn Jones, Simon Jeffrey, Thorum Petursdottir \\ and Luca Montanarella
}

\begin{abstract}
Introduction: A framework is developed to link major soil functions to ecosystem services assessment. Provisioning soil functions - with primary linkages to ecosystem services - are evaluated on a continental scale in Europe.

Methods: We defined major provisioning soil functions combining the approaches proposed by the Millennium Ecosystem Assessment and the Thematic Strategy for Soil Protection of the European Union. Soil productivity was evaluated by three main land use types (cropland, grassland, forest) using a validated expert model called SoilProd. Models include soil, climate and topographic criteria. Raw material provision capacity of soils was assessed on the basis of (i) organic carbon content and (ii) availability of soil materials for construction.

Results: A coherent system of soil function-based ecosystem services was compiled, taking into account major soil functions. We also produced new data on soil-based provisioning ecosystem services, including productivity and raw material availability. The attempts to cover the main human activities requiring materials of soil origin and to map the locations where those materials are available on a continental scale provide new insight to this field of research.

Conclusions: Soil-based ecosystem services can be assessed by the evaluation of soil functions which play a role in the production of these services. Quantitative analysis and comparison of the spatial distribution of the investigated soil functions were performed.

While crop productivity showed a general trend to increase in a northward and westward direction, local soil quality in most regions - except in the Mediterranean — can compensate for climatic handicaps to a great extent. Comparison of areas with potential for providing ecosystem services by individual soil functions highlights the complexity of decision-making for resource utilization but also the possibilities for optimization and more conscious management.
\end{abstract}

Keywords: Soil ecosystem services; Provisioning functions; Soil productivity; Soil quality; Land evaluation

\section{Introduction}

Soil plays a crucial role in terrestrial ecosystems and in maintaining life on Earth. Its functions which support ecosystem services to humans are manifold and complex.

This paper proposes a framework for the evaluation of soil functions that play a role in ecosystem services on a continental scale across Europe and offers an account of the repertoire of major soil functions and functional capacities of soils. Soil functions and associated services are discussed in the context of the European Union's

\footnotetext{
* Correspondence: gergely.toth@jrc.ec.europa.eu

Joint Research Centre, Institute for Environment and Sustainability, Via Fermi 2749 TP280, Ispra 21027, Italy
}

Thematic Strategy for Soil Protection and are related to the concepts of the Millennium Ecosystem Assessment.

The attempt to characterize soil functions and ecosystem services for the terrestrial area of the EU in a spatially explicit manner is based on new data on provisioning soil ecosystem services, including productivity and raw material availability. Quantitative comparisons between major climatic zones of Europe were made with regards to the capacity of the soil to carry out provisioning functions.

Comparing the potential of individual soil functions across the EU highlights the complexity of decisionmaking dilemmas for resources utilization but also 
underlines the possibilities for resource use optimization and conscious management.

Soil plays a fundamental role in terrestrial ecosystems as a three-dimensional body that performs a wide range of ecological functions as a part of the services provided by ecosystems (Hannam and Boer 2004). The multitude of complex interactions which occur within the soil, including between biotic and abiotic compartments, gives rise to numerous soil functions (Blum 2005) which support ecosystem services, often viewed in terms of the services they provide to humans (De Groot et al. 2002; Fisher et al. 2009, Peccol and Movia 2012).

Soil functions are general or specific capabilities of soil to support various agricultural, environmental, landscape, and urban applications. Specific soil functions are manifold and may be grouped according to the Thematic Strategy for Soil Protection of the European Union (TSSPEU; CEC 2006) as (1) biomass production, (2) storing, filtering, and transforming nutrients and water, (3) hosting the biodiversity pool, (4) acting as a platform for most human activities, (5) providing raw materials, (6) acting as a carbon pool, and (7) storing geological and archaeological heritage. The focus of our current assessment has been on these seven major soil functions, which reflects our current scientific and policy perspectives towards Europe's soil resources (CEC 2006). Although the criticism may be valid that a scientific evaluation of soil functions as defined by a policy document is biased by current policy-driven perception, rather than being based purely on theoretical grounds (with possible windows towards applicability), it is generally accepted (FAO 1976) that, in addition to studying soils' natural phenomena, soil resources should also be evaluated from socioeconomic viewpoints. This viewpoint is also an aim of the Millennium Ecosystem Assessment (MEA; Reid et al. 2005), the first comprehensive attempt to characterize the complex interactions between the various functions of ecosystems from the viewpoint of their services to humans. Therefore, a soil assessment derived from the recommendations of the TSSPEU and within the framework of soil functions is well justified for continental-scale applications in Europe.

A number of other classification and evaluation schemes for ecosystem services have emerged in recent years (Robinson et al. 2013), including the TEEB Assessment (2010; The Economics of Ecosystems and Biodiversity), which proposed a modification of the MEA scheme. Recommendations to link soil functions and ecosystem services have also been developed for local- to nationalscale uses (Haygarth and Ritz 2009).

This paper aims to provide a framework to link major soil functions to ecosystem services assessment for continental-scale applications based on the concepts of the MEA and the TSSPEU. A further aim of the current paper is to provide an assessment of soil functions for provisioning services.

\section{Methods}

\section{Concept of the assessment}

The capacity of soil to perform any of the seven identified functions and to support their associated ecosystem services depends on its physical, biological, and chemical attributes (i.e., "internal" characteristics), while the realization of the performance is conditioned by natural (e.g., slope steepness) and/or anthropogenic factors ("external" controls). In order to provide quantitative figures on the levels of soil functions which are valid in the spatial context of the diverse biophysical regions of the European Union, evaluation of soil functions has to be extended and combined with landform and climatic information. As soil quality - the capacity of soil to perform its functions-is a time-dependent dynamic phenomenon (Karlen et al. 2001; Larson and Pierce 1991), detecting temporal changes in soil functioning capacities is only possible if soil attributes are monitored. Since a comprehensive soil monitoring network and derived spatial database are lacking in Europe, the ambition to provide dynamic information on soil functions is unrealistic. However, characterizing soil functioning capacities on the basis of existing databases and matching this information with available land use and climate data were deemed feasible.

Most soil functions are interdependent; one function is not performed in isolation from another. Yet individual soil functions can be characterized by their primary linkages to ecosystem services and thus to services they provide to society, as is necessary for ecosystem services evaluation. Table 1 provides a framework proposed for continental-scale assessments. In the MEA, the process of soil formation, along with nutrient cycling and photosynthesis, was classified as an essential supporting service that facilitated other ecosystem services (i.e., provisioning, regulating, and cultural). As this study is concerned with soil functions, rather than underlying soil processes, a scheme modified from the MEA has been adopted, where soil functions are linked to ecosystem services through specific direct and indirect services provided by them.

\section{Soil functions that play a direct role in provisioning ecosystem services}

Soil functions include material outputs from soil, which can be organic or inorganic in nature. Organic materials include living aboveground biomass and subsurface organic matter. Inorganic materials include all forms of mineral compounds in the soil.

Biomass production and raw material provision are the two soil functions with material end products which are directly used by humans. However, it needs to be 
Table 1 Soil functions that play a role in ecosystem services either directly, through their primary benefits to humans, or indirectly, by contributing to ecosystem functioning that eventually leads to benefits for humans

\begin{tabular}{|c|c|c|c|c|c|}
\hline \multirow{2}{*}{$\begin{array}{l}\text { Soil functions } \\
\text { (CEC 2006) }\end{array}$} & \multirow{2}{*}{$\begin{array}{l}\text { Type of } \\
\text { linkage }\end{array}$} & \multicolumn{4}{|c|}{ Ecosystem services (MEA 2003) } \\
\hline & & Supporting & Provisioning & Regulating & Cultural \\
\hline \multirow[t]{2}{*}{$\begin{array}{l}\text { Biomass } \\
\text { production }\end{array}$} & Direct & & $\begin{array}{l}\text { Providing food, } \\
\text { feed, wood, } \\
\text { fiber, biofuels }\end{array}$ & & \\
\hline & Indirect & $\begin{array}{c}\text { Supporting } \\
\text { ecosystem } \\
\text { functions through } \\
\text { primary production }\end{array}$ & & $\begin{array}{l}\text { Regulating } \\
\text { carbon } \\
\text { sequestration }\end{array}$ & $\begin{array}{l}\text { Contributing to } \\
\text { traditions, } \\
\text { spiritual } \\
\text { inspiration }\end{array}$ \\
\hline \multirow{2}{*}{$\begin{array}{c}\text { Storing, } \\
\text { filtering and } \\
\text { transforming } \\
\text { nutrients and water }\end{array}$} & Direct & & & $\begin{array}{l}\text { Regulating water } \\
\text { and nutrient } \\
\text { availability }\end{array}$ & \\
\hline & Indirect & $\begin{array}{c}\text { Supporting } \\
\text { ecosystem } \\
\text { functions through } \\
\text { water and nutrient } \\
\text { cycling }\end{array}$ & & & \\
\hline \multirow[t]{2}{*}{$\begin{array}{l}\text { Hosting } \\
\text { biodiversity }\end{array}$} & Direct & $\begin{array}{c}\text { Supporting } \\
\text { ecosystem } \\
\text { functioning by } \\
\text { hosting biodiversity }\end{array}$ & & & \\
\hline & Indirect & & $\begin{array}{c}\text { Providing } \\
\text { pharmaceuticals } \\
\text { and biochemicals } \\
\text { through gene } \\
\text { reserve }\end{array}$ & $\begin{array}{l}\text { Regulating crop } \\
\text { pollination, } \\
\text { pest, and disease } \\
\text { control through } \\
\text { living organisms }\end{array}$ & $\begin{array}{l}\text { Contributing to } \\
\text { scientific } \\
\text { discovery }\end{array}$ \\
\hline \multirow[t]{2}{*}{$\begin{array}{c}\text { Platform for } \\
\text { human activities }\end{array}$} & Direct & $\begin{array}{l}\text { Supporting human } \\
\text { habitats }\end{array}$ & & & \\
\hline & Indirect & & & & \\
\hline \multirow[t]{2}{*}{$\begin{array}{c}\text { Source of raw } \\
\text { materials }\end{array}$} & Direct & & $\begin{array}{l}\text { Providing } \\
\text { minerals and } \\
\text { soil organic } \\
\text { matter }\end{array}$ & & \\
\hline & Indirect & & & & \\
\hline \multirow[t]{2}{*}{ Carbon pool } & Direct & & & $\begin{array}{l}\text { Regulating } \\
\text { atmospheric } \\
\mathrm{CO}_{2}\end{array}$ & \\
\hline & Indirect & $\begin{array}{l}\text { Supporting soil } \\
\text { structure, nutrient } \\
\text { capacity, etc. }\end{array}$ & & $\begin{array}{l}\text { Regulating soil } \\
\text { system }\end{array}$ & \\
\hline \multirow[t]{2}{*}{$\begin{array}{c}\text { Storing } \\
\text { geological and } \\
\text { archaeological } \\
\text { heritage }\end{array}$} & Direct & & & & $\begin{array}{c}\text { Cultural heritage } \\
\text { values (natural } \\
\text { sciences, history, } \\
\text { and anthropology) }\end{array}$ \\
\hline & Indirect & $\begin{array}{l}\text { Geological heritage } \\
\text { supporting the } \\
\text { maintenance of } \\
\text { ecosystem dynamic } \\
\text { equilibrium }\end{array}$ & & & \\
\hline
\end{tabular}

stressed that biomass production is a renewable function of soil, while the provision of raw material in most cases is destructive for the soil body. This distinction needs to be considered when planning for sustainable soil use.

To evaluate the performance of the biomass production function, traditional biophysical land evaluation methods can be used. For the evaluation of the raw material provision functions, the definition of the criteria for soiloriginated raw material needs to be established. Firstly, it is important to set distinct criteria for soil and non-soil materials. Most mineral raw materials used by humans are of geological origin and are generally excavated by mining operations. Although soil parent material is usually considered as part of the pedon (e.g., soil taxonomy), in the raw 
material provisioning soil service, only soil layers above the parent material are considered. This designation also corresponds to the soil characterization provided by the TSSP, according to which "soil is generally defined as the top layer of the Earth's crust, formed by mineral particles, organic matter, water, air and living organisms" (CEC 2006).

Based on the above considerations, the biomass production function and raw material availability in the soil layers above the parent material were assessed during the evaluation of provisioning soil ecosystem services.

Biomass production of a given soil depends on the geographic location (climatic, hydrological, and terrain conditions), the land use type, land management, and the vegetation under consideration. In a continentalscale assessment, a land use-specific evaluation should be performed for the main biomass-producing land use types, namely cropland, grassland, and forest.

For continental-scale evaluations of raw materials in soils we must limit ourselves to the issues apparent over larger areas. While acknowledging the significance of locally important soil characteristics (such as high quality kaolinite for ceramics; bentonite for metal casting, well drilling, or food additives; clay for various applications), this study has focused on two applications: (1) organic soil (for horticultural and other applications) and (2) soil materials in construction. These two fields of applications involve by far the largest amounts of excavated soils in Europe. It is worth noting that a regional or local soil quality assessment might consider other elements (and with different weights). It is also worthwhile to mention that the growing demand for the services provided by the genetic pool of soil biota (e.g., from pharmaceutical industry) might lead to extraction of some soil material locally. However, the magnitudes of these kinds of extractions involve minor areas on the local scale and are not significant on a regional scale, and as such do not significantly affect the capacity of soil to provide other ecosystem services.

Attention should be called to the major difference between renewable biomass production and destructive use of soil substances. Authors strongly stress the need for considering sustainable soil use with regards to provisioning soil functions.

\section{Databases \\ Soil data}

The European Soil Database (ESDB; EC 2003) was used as the soil information source in this study. Specifically, the Soil Geographical Database of Eurasia (SGDBE) and the PedoTransfer Rules Database (PTRDB) components of the ESDB were utilized.

The SGDBE, at scale 1:1,000,000, and the PTRDB are parts of the European Soil Information System (Panagos 2006; van Liedekerke et al. 2004). The SGDBE consists of both a geometric dataset and a semantic dataset (set of attribute files) which link attribute values to the polygons of the geometrical dataset. The database contains a list of soil typological units (STU). Besides the higher level soil taxonomic classification units represented by a soil name, these units are described by variables (attributes) specifying the nature and properties of the soils, for example, texture, water regime, or stoniness. As the original taxonomic information of the SGDBE is based on the 1990 FAO-UNESCO Soil Revised Legend (FAO 1990), these names and associated information content are used in the current exercise.

The PTRDB consists of a set of rules to derive new attributes with input attributes of the SGDBE (EC 2003). Pedotransfer rules related to water availability were applied in this study.

\section{Land use data}

The land use data of the SGDBE were exploited during the biomass productivity evaluation. The SGDBE holds information on dominant and secondary land use types of each component STU of the soil map polygons. For cropland productivity evaluation, only those STUs were considered which had cultivated land as primary or secondary land use type in the SGDBE.

The GLOBCOVER dataset developed by the European Space Agency (Bicheron et al. 2006) was used to restrict the study area separately for the main land cover classes during the validation process.

The CORINE (CO-oRdination of INformation on the Environment; JRC-EEA 2005) land cover database for the year 2000 was used to select the extent of different land use types (cropland, grassland, forest land) to present the results.

\section{Climate data}

Europe has diverse climatic conditions, represented by climatic zones and areas (FAO 1990; Köppen 1936). Rainfall characteristics and temperature regime seem to provide sufficient information for continental-scale agrometeorological zonalization (Bouma 2005). The limiting effect of solar radiation is less articulated in most of Europe than that of rainfall or temperature. Differences in the radiation intensity can therefore be expressed through the above two factors and through terrain characteristics (slope and its orientation).

Soil quality evaluation for biomass productivity was therefore performed in a spatially explicit manner, taking the impact of the climatic component of soil productivity into account. Climatic zonation based on the 35 climatic areas of Hartwich et al. (2005) served as spatial units for soil productivity assessments on the continental scale. Regrouping of the climatic areas was performed to create climatic zones for soil quality assessment (Figure 1). 
Crop and forest stand requirements regarding climatic conditions might differ to a great extent. For forest land, the length of the vegetative season and the soil water balance, calculated based on potential evapotranspiration (ETO; Penman 1948), were the aspects taken into consideration for the evaluation of forest productivity.

\section{Topographic data}

A digital elevation model (DEM) was used to include a topographic component in the land evaluation model. The applied DEM was derived from the Shuttle Radar Topography Mission (SRTM; Rabus et al. 2003), which provided a dataset with a grid cell of $90 \mathrm{~m}$.

\section{Validation datasets}

In order to address the scientific reliability of the developed biomass productivity models, a validation procedure was applied using an independent dataset. A remote sensing-derived productivity indicator was used to validate all three land use-specific soil productivity models independently.

SPOT VEGETATION ${ }^{\mathrm{a}}$ decadal data were used to derive an approximation of biomass for the whole European continent. Data from the VEGETATION Program are frequently used in global and continental studies that supply input to General Circulation Models derived from measurements of the land cover and of the seasonal and long-term variations in vegetation dynamics. Studies that address the effect of biosphere processes and land cover characterization, the estimations of land cover variables as well as their dynamics, and the quantification of the mechanisms by which vegetation cover and ecosystems are interlinked all benefit from the VEGETATION Program. The SPOT data were corrected for system errors (misregistration of the different channels, calibration of all detectors along the line-array detectors for each spectral band) and resampled to geographic projections for multitemporal analysis as well as for comparison with high resolution data. For the present study, the 10-day synthesis or the maximum Normalized Difference Vegetation Index (NDVI) composite was used as is commonly accepted in the scientific community.

The NDVI time series was smoothed in order to remove short peaks and drop-offs due to noise. This preprocessing resulted in the reference time series from which the first (January) and last (December) absolute minimum values were derived for each year. The integral surface under the NDVI curve defined by the first and last minima of the year was derived and used as the approximation of net primary production (NPP; Figure 2). Ten years of NPP values were averaged for each pixel, and a final NPP dataset was produced (Figure 3). Many studies have already discussed the use of the integral surface of the annual NDVI time series curve as an approximation of aboveground biomass production (for an overview see Hill et al. 2008; Hellden and Tottrup 2008). In the present study the NPP dataset was used to validate the soil productivity model in a geographically explicit manner.

For the raw material provisioning service, no validation datasets are available, therefore no similar validation was performed for this model.

\section{Evaluation of soil provisioning functional capacities Biomass production}

The degree to which the soil carries out its biomass production service was evaluated on the basis of soil properties under prevailing climatic and topographical conditions. Since productivity is a result of the interaction of soil, climatic, and topographical conditions, these factors need to be assessed in their complexity.

In addition to geophysical conditions, soil productivity also depends on the type of land use. The assessment of the European Environmental Agency (EEA 2006) shows that the three major land use types dominating the land cover of Europe are arable land with a share of 33\%, pastures and mosaics with a share of $23 \%$, and forests with a share of $29 \%$. The aggregated share of these three types of land uses sums up to $85 \%$ of the total land and freshwater surfaces of the 24 countries of Europe assessed by the EEA (2006). Besides these major land use types, there are a number of specific regionally characterized land uses in Europe. There might also be considerable differences in the land utilization within the main land use types. However, for a continental-scale assessment of biomass productivity, the productivity patterns were evaluated according to the three major land use types. Models were therefore developed to describe general orders of soil productivity within the three land use types, namely for pasture/grassland, cropland, and forest.

Calculations were performed in a spatially explicit manner, taking climatic and topographical conditions into account. Productivity models were built to reflect rain-fed conditions. The description of temporal variability of productivity or the estimation of provision productivity by means of actual yields was not among the aims. Results are presented in land use-specific maps (e.g., cropland productivity for areas of rain-fed arable lands, forest biomass productivity for forest lands, and grassland productivity for pastures and mosaics).

\section{Biomass production on grasslands and arable lands}

Productivity differences of similar soils under intensive rain-fed agricultural use and under grassland land cover vary with the changing availability of precipitation and differences in temperature regimes. For instance, in a 


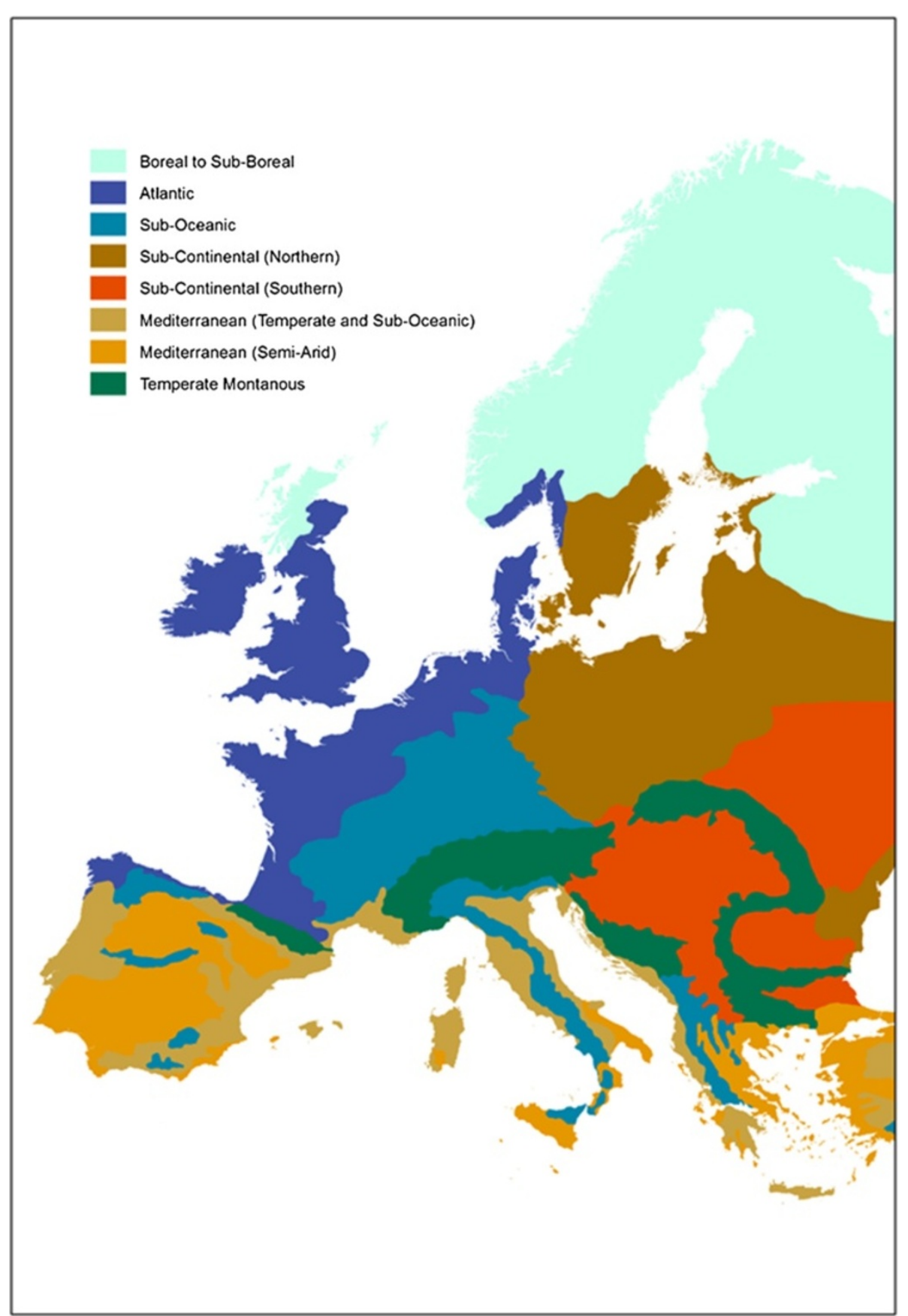

Figure 1 Climate zones of the study.

temperate sub-oceanic climate, the rather stable thermal regime and balanced water availability of medium to high amounts of precipitation not only secure plantavailable water on most soil types throughout the growing period but facilitate decomposition and weathering throughout the year. These processes are limited under temperate continental and Mediterranean climates due to cold and/or arid periods in most years. With increasing aridity in prevailing climates, the importance of soil physical and chemical properties in water and nutrient supply to plants gains increasing significance. Based on this principle of soil productivity processes, ranking of inherent productivity of soil was performed separately for the major climatic areas. While fertility is defined as the ability of the soil to provide nutrients and water, productivity refers to the capacity to supply nutrients 


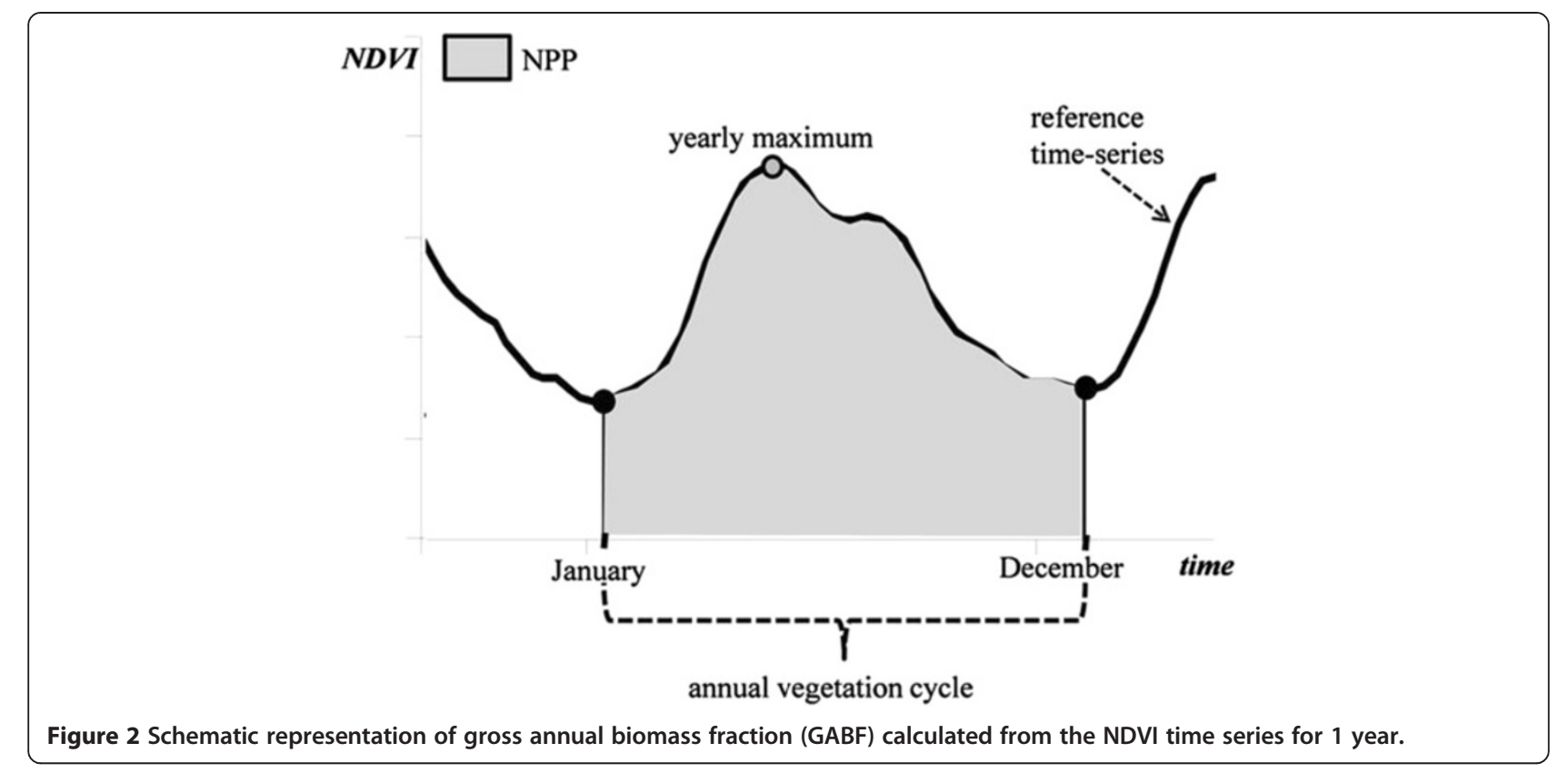

and water and thus produce plant biomass at a given level/ quantity. Inherent productivity in this context means soil productivity before human interference. In this study, inherent soil fertility-in this context productivity-is considered as a proxy for grassland productivity. Although the existence of different nutrient inputs on grasslands in different regions of the European Union is recognized, due to the lack of adequate data, grassland fertilization and other management factors were not taken into account. Cropland soil productivity was evaluated by the extension of inherent productivity with a management factor, as described below.

\section{Grassland/pasture}

In the first step of the evaluation process, eight characteristic European climate systems were identified where the complex effects of water availability and thermal regime are distinct for soil processes and plant growth. The 35 climatic areas of Europe (Hartwich et al. 2005) were arranged into eight climatic groups accordingly (Figure 1). The climatic groups comprise regions where the following concepts of soil productivity processes prevail: boreal to sub-boreal (CZ1), Atlantic (CZ2), sub-oceanic (CZ3), northern sub-continental (CZ4), southern sub-continental, (CZ5), Mediterranean semi-arid (CZ6), Mediterranean (temperate and sub-oceanic) (CZ7), and temperate mountainous (CZ8). Long-term average inherent soil productivity ratings were assigned to soils of each region in a spatially explicit manner. Temporally variably climatic hazards of productivity (frost, water logging, etc.) were not taken into account in the current study.

Inherent soil productivity estimates were derived from the original taxonomic component (second-level taxonomic soil units) and soil attribute information of the soil database.
Second-level taxonomic soil units were grouped into five inherent capability classes according to their relative productivity in each climatic zone. CZ1 includes 59 different soil units, CZ2 has 113, CZ3 has 122, CZ4 has 117, CZ5 has 128, CZ6 has 96, CZ7 has 103, and CZ8 has 131. This approach allows productivity assessment of soil types at different climatic regions. Table 2 provides an example of the classification.

In parallel, STUs were also rated according to the available water capacities (AWC) of topsoil and subsoil. According to the pedotransfer rules of the PTRDB (EC 2003) and based on physical soil properties and soil depth, AWCs of both the topsoil and the subsoil were calculated. Soils were grouped into four classes on the basis of the water-storing capacity of the profile (Table 3 ).

In the next step of the productivity assessment, an evaluation matrix was set up for the eight climatic regions and the five inherent capability classes. Productivity scores between 1 and 8 were assigned for each cell in the matrix, based on the complex evaluation of the climate-dependent relative inherent fertility of soils (Table 4).

Water-storing capacity classes (Table 3 ) were assigned a multiplication factor between 0.75 and 1 for each climate zone. These factors were used to multiply the productivity scores of each soil unit of the climate zones.

The position of soil units in the capability classification matrix, productivity scores of capability classes by climate zones, and multiplication factors to account for the waterstoring capacities by climate zones were first defined by expert judgment and then refined and completed through an iterative analytical process with a series of cross validations using regression analysis (GWR) with the validation dataset 


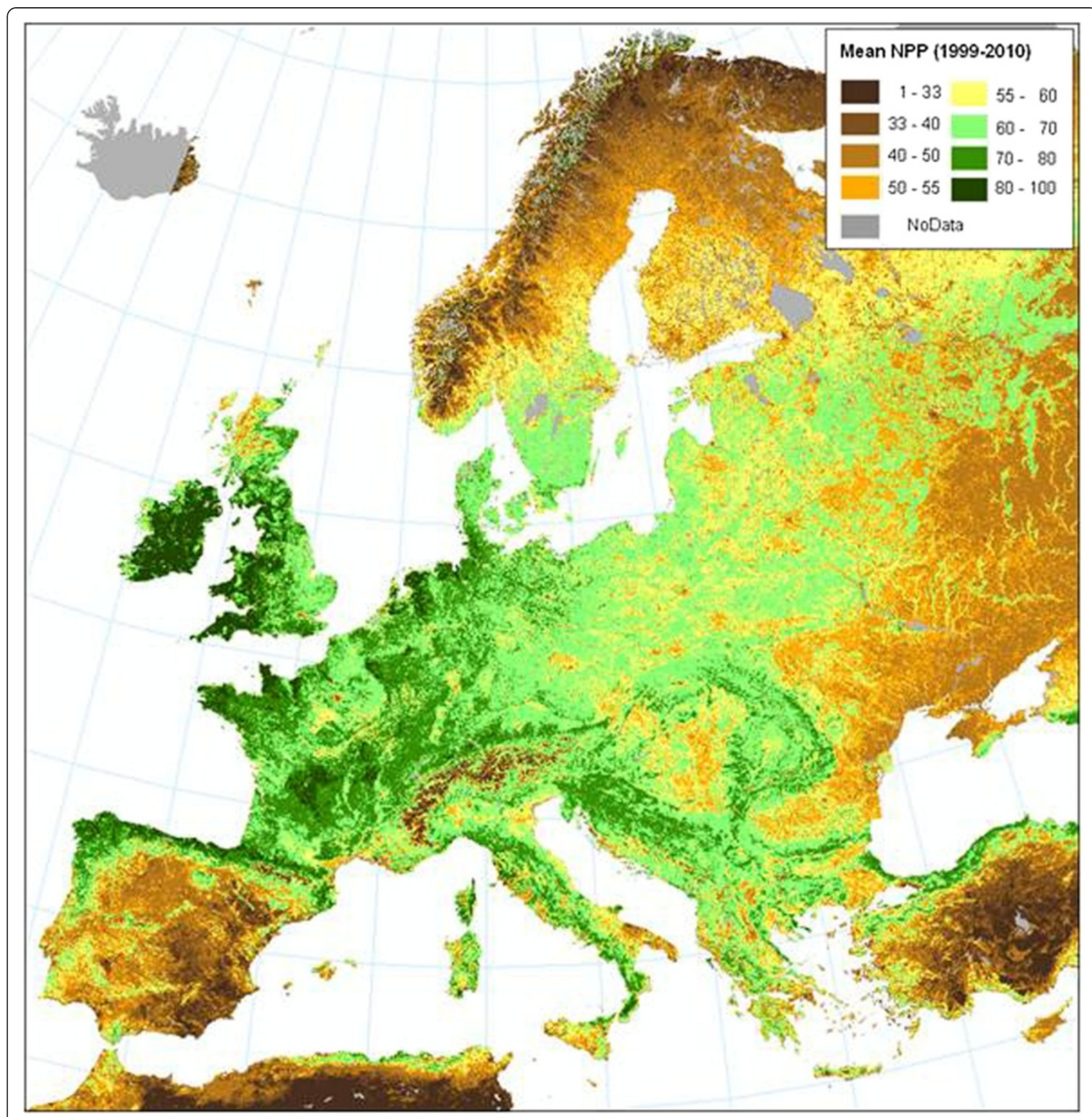

Figure 3 Mean GABF derived from time series of SPOT VEGETATION NDVI images averaged over the time series 1999-2010 for Europe.

as dependent variable (see below for details on the validation process).

The result of this procedure is the soil productivity index for each soil typological unit in the climate zones. The index score 1 represents the poorest and 8 the highest productivity soil. The corresponding inherent productivity scores were assigned to each STU in the SGDBE. A spatially weighted average of inherent productivity score was calculated for each soil mapping unit on the basis of the proportional areal shares of the STUs within the mapping units.
Correction measures based on topographic conditions were finally applied to arrive at the final evaluation scores of inherent soil productivity. Correction coefficients of slope and aspects applied according to the D-eMeter land evaluation system (Tóth 2009) were adapted for this continental-scale study.

\section{Croplands}

To evaluate the biomass productivity of soils under arable cultivation, the model was extended with a new module. 
Table 2 Examples of climate-zone-based productivity classification reference (10 soil units out of the total 128 present in the southern sub-continental climate zone are displayed here)

\begin{tabular}{ccccc}
\hline \multicolumn{4}{c}{ Inherent capability classes (southern sub-continental climate) } \\
\hline V. & IV. & III. & II. & I. \\
Calcaric Lithosol & Orthic Rendzina & Gleyo-Dystric Luvisol & Albic Luvisol & Haplic Phaeozem \\
Gleyic Solonchak & Gleyic Podzoluvisol & Dystric Regosol & Chromic Cambisol & Luvic Chernozem \\
\hline
\end{tabular}

Since the productivity of soil is due to its inherent fertility and to the effect of management-mainly nutrient inputthe effect of fertilization was considered in this module. While acknowledging the importance of the applied technology of soil use on the actual productivity of soil, detailed distinctions of management practices were not considered in this study. The goal of this study was solely to determine soil productivity, i.e., the capacity of soil to supply nutrients, water, and rooting medium for plants, in a comparative manner and not to assess the effects of management differences other than nutrient supply. We also assume that in the case of the realization of biomass productive capacity, technological advancement plays a relatively insignificant role within distinct regions in European Union. However, in certain regions, where complex socioeconomic and biophysical conditions diversify the technological levels, this statement might not hold. The efficiency of input use, i.e., the selection of the most appropriate techniques and the amount of input, is largely determined by biophysical conditions (e.g., large regional crop yield differences within France (Eurostat 2013), are due to biophysical differences rather than differences in available technology, capital, or other socio-economic conditions). However, the technological advancement and input intensity of agriculture across regions in the European Union varies, and this variation contributes to differences in crop yields.

It was not the goal of this study to evaluate all management-related yield responses of soils, but rather, to evaluate the effect of management, we considered the influence of fertilization. To do this, second-level taxonomic soil units were grouped into five classes in each climatic zone, according to the magnitude of their

Table 3 Examples of water-storing capacity classifications

\begin{tabular}{llll}
\hline $\begin{array}{l}\text { Water-storing } \\
\text { capacity classes }\end{array}$ & $\begin{array}{l}\text { AWC of } \\
\text { topsoil }\end{array}$ & $\begin{array}{l}\text { AWC of } \\
\text { subsoil }\end{array}$ & $\begin{array}{l}\text { Depth to } \\
\text { impermeable layer }\end{array}$ \\
\hline I. & Very high & Very high & Deep \\
II. & High & Very high & Deep \\
& Medium & High & Deep \\
III. & High & Medium & Deep \\
& Medium & Low & Deep \\
IV. & High & Very low & Deep \\
& High & Very low & Shallow \\
& Medium & Low & Shallow \\
\hline
\end{tabular}

expected productivity increase due to fertilization (Table 5).

Then, a fertilizer response score was assigned to each soil unit in the eight climatic zones. Soils with the largest relative fertility increase received the maximum of 8 points and soils with little influence of fertilization received 1 point. For example, an Albic Arenosol in the sub-oceanic climate has among the highest relative productivity increases when properly fertilized, while fertilization has little effect on the crop productivity of Calcaric Rendzinas in the Mediterranean.

To calculate soil productivity for the cropland land use type, the inherent soil productivity and the fertilizer response scores were aggregated, assigning a mechanical weight to the fertilizer response indices. This weight resulted in the best model fit at the end of an iterative statistical validation process (see below for details of the statistical validation). Spatially weighted averages of productivity scores were calculated for the SMUs of the SGDBE. In order to avoid the bias originating from the evaluation of non-cropland soils, only those STUs were considered which had cultivated land as the primary or secondary land use type in the SGDBE. Finally, similarly to the concluding step of the grassland productivity evaluation, correction coefficients were applied to evaluate the effect of the topography (slope and aspect) on the productivity of cropland soils.

\section{Biomass production on forest lands}

The productivity of a forest, in terms of biomass, is the result of the interaction of tree species, soil, and climate. Ecosystem research has provided sufficient information about key processes such as photosynthesis, transpiration, and

Table 4 Productivity scores for the soil capability classes by climatic zones

\begin{tabular}{lllllllll}
\hline CZ1 & CZ2 & CZ3 & CZ4 & CZ5 & CZ6 & CZ7 & CZ8 & Score \\
\hline I. & II. & I. & I. & & & & I. & 7 \\
II. & III. & II. & II. & & I. & I. & II. & 6 \\
III. & IV. & III. & III. & I. & II. & II. & III. & 5 \\
IV. & V. & IV. & IV. & II. & III. & III. & IV. & 4 \\
V. & & V. & V. & III. & IV. & IV. & V. & 3 \\
& & & & IV. & V. & V. & & 2 \\
& & & & V. & & & & 1 \\
\hline
\end{tabular}


Table 5 Sample reference table for classifying the response of different soil types to fertilization on a climate zone basis (10 of 128 soil units present in the southern sub-continental climate zone are shown here)

\begin{tabular}{ccccc}
\hline \multicolumn{4}{c}{ Fertilizer response classes (southern sub-continental climate) } \\
\hline V. & IV. & III. & II. & I. \\
Luvic Ranker & Eutric Gleysol & Calcaric Phaeozem & Albic Luvisol & Dystric Fluvisol \\
Cambic Rendzina & Chromic Vertisol & Dystric Podzoluvisol & Calcic Cambisol & Calcaric Cambisol \\
\hline
\end{tabular}

decomposition to allow the construction of simulation models that predict properties such as biomass production, soil carbon storage, and nitrogen cycling rates (e.g., Aber et al. 1997; Parton et al. 1988; Raich et al. 1991; Running and Gower 1991).

Several of these models are based on complex input data sets, consisting of a series of climate, soil, and forest stand data (i.e., maximum and minimum daily temperature, vapor pressure, solar radiation, total monthly precipitation, forest type, and plant-available soil water holding capacity).

The aim of this study, however, was to predict, in general terms, the forest productivity potential of European soils. For this purpose, two main processes related to forest productivity were evaluated: the length of the vegetative season and the soil water balance. The concept behind this simplistic approach is that the net ecosystem productivity (NEP) of a forest can be limited by two main factors: the air temperature, which determines the length of the vegetative season, and the amount of water from soils that the plants can evapo-transpire. Accordingly the northern latitude forests will be limited by the relatively short vegetative season, while the Mediterranean forests will be limited by the relatively low water availability, which in turn is related to both climate and soil characteristics.

The equation used for the calculation of forest productivity is shown below:

$$
\begin{aligned}
& \text { Forest productivity }=(\text { SWBNx } / \text { SWBNmax }) \\
& \times \text { vegetative length }
\end{aligned}
$$

where SWBNx is the soil water balance normalized at a given location $(\mathrm{mm}), \mathrm{SWBNmax}$ is the maximum soil water balance $(\mathrm{mm})$, and vegetative length is the length of the vegetative season (days). The soil water balance is calculated as:

$$
\Sigma(\mathrm{Pi}-\mathrm{ETPi})+\mathrm{AWC}(\mathrm{mm})
$$

where Pi is monthly precipitation, ETPi is monthly potential evapotranspiration $(\mathrm{Kc}=1)$, and $\mathrm{AWC}$ is the available water content ( $\mathrm{mm})$.

The values obtained, ranging from 0 to 313 , were grouped into 10 equal classes. The output map was masked based on the actual forest distribution as defined by the CORINE Land Cover database.
Results of all three productivity evaluations (grassland, cropland, forest) were scaled to index scores ranging from 1 to 10 showing the relative fertility of soils expressed in relative index values without units.

\section{Provisioning raw materials}

The evaluation of raw material availability from soil origin is limited to resources above the parent material. The assessment included the following two options, with the relevant criteria:

a) Peat (for horticultural and other applications) and organic topsoil: All organic soils (Histosols) are considered and no mineral soils are considered.

b) Soil materials for construction: To assess the quality of soils to provide construction materials, the approach presented in the Soil Atlas of Europe ${ }^{b}$ was applied, and the presence of sand and gravel was examined for this function. Criteria:

a. Coarse texture (clay $<18 \%$ and sand $>65 \%$ ) and/or

b. Stones and gravel content are dominant in the horizon ( $>80 \%$ by volume)

In addition to the above construction materials, loamy clay is often used to produce bricks and tiles. Although the Soil Atlas of Europe does not consider these as among the dominant soil-based construction materials, their widespread usage could justify the inclusion of loamy-clay (sub) soils in the analysis. However, the currently available continental soil databases contain no information on soil texture at this level of detail; therefore such an analysis was not feasible at this time.

The evaluation did not account for any economic considerations (i.e., only the availability of raw material was assessed). Results are presented as the proportional availability of these materials in the mapping units. For Cyprus, no information on texture and stone and gravel content was available and, therefore Cyprus was excluded from this analysis.

\section{Statistical validation}

The geographically weighted regression (GWR) method (Brunsdon et al. 1996; Fotheringham et al. 2002) was selected to validate the model results against the measured productivity indicators. The GWR method was selected 
as it allows for the possibility of assessing relationships in spatially explicit information. Spatial data are rarely consistent due to random sampling variations, the different relationships between variables across space, or model misspecifications of reality (Fotheringham et al. 2002). However, the application of standard regression methods to spatial data would result in the assumption of the spatial phenomenon being constant over space.

GWR is a statistical technique that allows the modeling of processes that vary spatially. Consider the ordinary least squares (OLS) regression model given by

$$
y_{i}=a_{0}+\sum_{k} a_{k} x_{i k}+e_{i}
$$

where $e_{i}$ is the error term, $a$ represents the vector of global parameters to be estimated, $x$ is a matrix of independent variables and $y$ represents a vector of observations on the dependent variable.

GWR extends the traditional regression framework by allowing local rather than global parameters to be estimated. Thus the OLS regressions model is rewritten as:

$$
y_{i}=a_{0}\left(u_{i}, v_{i}\right)+\sum_{k} a_{k}\left(u_{i}, v_{i}\right) x_{i k}+e i,
$$

where $\left(u_{i}, v_{i}\right)$ denotes the coordinates of the $i$ th point in space and $a_{k}\left(u_{i}, v_{i}\right)$ is a realization of the continuous function $a_{k}(u, v)$ at point $i$ (Brunsdon et al. 1996).

This extension allows measurements of a continuous surface of parameters to be taken and to denote the spatial variability of the surface because observed data near point $i$ have more of an influence in the estimation than do data located farther from $i$. Thus GWR becomes a weighted least squares regression where observations are weighted in accordance with the proximity to point $i$ and the weight decreases with increasing distance from with $i$.

The biomass productivity spatial datasets were dividedboth from our land evaluation exercise and from the satellite observations-by land use, based on small regions for special diagnoses (NUTS3; Eurostat 2011). Analyses of statistical correlation between the datasets were performed using the GWR method as described above.

Per pixel biomass values estimated from the land evaluation exercise and from the satellite-based observations were averaged within the regions of the NUTS3 dataset (Eurostat 2011) for the countries of the European Union. The GWR analysis was carried out separately for croplands, grasslands and forests with the remote sensingderived biomass estimates as the dependent variable and the land cover-specific biomass estimates as independent variables. Each regression run was weighted by the number of pixels within the NUTS3 polygons.
The result of the GWR model for croplands is valid with a goodness of fit characterized by a coefficient of determination (adjusted $\mathrm{r}^{2}$ ) of 0.73 . The adjusted $\mathrm{r}^{2}$ figure for grassland is 0.85 and for forests 0.90 . These results can be considered as a confirmation of the validity of the soil productivity evaluation approach.

\section{Results and discussions}

\section{Grassland soil productivity map of the EU}

The application of a geographically explicit spatial soil grassland productivity model showed high consistency with the data obtained from remote sensing $\left(R^{2}=0.85\right)$.

Based on the cumulative relative productivity indices, the soils in the Atlantic climatic zone have the highest potential for grassland production. They contribute nearly half of the potential for the European Union (44.6\%), although only $38.4 \%$ of Europe's grassland areas are found in the Atlantic zone (Table 6). The zone productivity factor of grassland soils in this climate zone is 1.2 , indicating $20 \%$ higher relative productivity indices on average when compared to the mean of the EU. In contrast, grasslands of the semi-arid Mediterranean region have relative productivity indices that are $40 \%$ lower than the average of the EU. Apart from the northern sub-continental zone (zone productivity factor $=1$ ), all other zones have relative productivity indices for grasslands that are lower than the average of the EU. This fact indicates that, in most of the climatic zones (CZ1, CZ3, CZ5, CZ6, CZ7, CZ8) of Europe, grassland ecosystems are on soils of lower production potentials.

The dependency of productivity on climate was statistically significant at the continental scale. Up to an estimated average of $60 \%$ of the grassland productivity differences between the most favorable (Atlantic) and least favorable (Mediterranean semi-arid) regions of the EU can be attributed to climatic factors, as indicated by the differences in mean productivity indices between the climatic zones and standard deviations within the climatic zones (Table 6). The influence of regional soil variability expressed as the standard deviations of the soil productivity indices might exceed the figure attributed to the influence of climate between different climate zones. These results confirm the general understanding of the importance of water availability in soil and the synergism between optimum temperature, water, and nutrient regimes and also present these interdependencies in a quantified manner in a spatial context.

Results of the inherent soil productivity evaluation are shown in the grassland productivity map of the European Union (Figure 4).

\section{Cropland soil productivity map of the EU}

A comparative analysis between modeled and remote sensing-derived soil productivity indicators demonstrated a significant climate dependency in the general pattern of 
Table 6 Summary statistics of productivity indices for soils in the European Union by major land use classes and main climatic zones

\begin{tabular}{|c|c|c|c|c|c|c|c|}
\hline \multirow{2}{*}{$\begin{array}{l}\text { Climate } \\
\text { zone }^{\mathrm{a}}\end{array}$} & \multicolumn{2}{|r|}{ Area } & \multicolumn{4}{|c|}{ Productivity index } & \multirow{2}{*}{$\begin{array}{c}\text { Zone } \\
\text { productivity } \\
\text { factor }^{c}\end{array}$} \\
\hline & $\mathrm{km}^{2}$ & Percentage of EU & Mean & Standard dev & Sum & Percentage of total ${ }^{b}$ & \\
\hline \multicolumn{8}{|c|}{ Grassland } \\
\hline 1 & 21,571 & 4.5 & 5.8 & 1.7 & 124,963 & 4.3 & 0.9 \\
\hline 2 & 184,363 & 38.4 & 7.1 & 2.1 & $1,305,600$ & 44.6 & 1.2 \\
\hline 3 & 88,910 & 18.5 & 5.8 & 2.0 & 515,760 & 17.6 & 0.9 \\
\hline 4 & 55,982 & 11.7 & 6.3 & 1.3 & 350,335 & 12.0 & 1.0 \\
\hline 5 & 33,309 & 6.9 & 5.8 & 1.2 & 192,966 & 6.6 & 0.9 \\
\hline 6 & 21,959 & 4.6 & 3.8 & 1.2 & 84,031 & 2.9 & 0.6 \\
\hline 7 & 16,170 & 3.4 & 4.2 & 1.3 & 68,612 & 2.3 & 0.7 \\
\hline 8 & 57,306 & 11.9 & 5.0 & 1.4 & 286,378 & 9.8 & 0.8 \\
\hline \multicolumn{8}{|c|}{ Cropland } \\
\hline 1 & 32,458 & 2.4 & 6.1 & 1.0 & 198,645 & 2.5 & 1.0 \\
\hline 2 & 308,693 & 23.0 & 7.1 & 1.3 & $2,189,030$ & 27.6 & 1.2 \\
\hline 3 & 170,655 & 12.7 & 5.7 & 1.6 & 974,337 & 12.3 & 1.0 \\
\hline 4 & 337,121 & 25.1 & 6.2 & 1.1 & $2,099,960$ & 26.5 & 1.1 \\
\hline 5 & 175,914 & 13.1 & 5.8 & 1.0 & $1,013,880$ & 12.8 & 1.0 \\
\hline 6 & 174,171 & 13.0 & 4.0 & 1.2 & 698,184 & 8.8 & 0.7 \\
\hline 7 & 109,687 & 8.2 & 5.0 & 1.2 & 545,528 & 6.9 & 0.8 \\
\hline 8 & 35,101 & 2.6 & 5.7 & 1.3 & 198,537 & 2.5 & 1.0 \\
\hline \multicolumn{8}{|c|}{ Forest } \\
\hline 1 & 531,907 & 30.9 & 2.3 & 0.8 & $1,202,780$ & 19.2 & 0.6 \\
\hline 2 & 120,702 & 7.0 & 5.0 & 1.7 & 606,879 & 9.7 & 1.4 \\
\hline 3 & 233,015 & 13.5 & 4.8 & 1.2 & $1,111,580$ & 17.8 & 1.3 \\
\hline 4 & 276,591 & 16.1 & 3.3 & 0.8 & 923,848 & 14.8 & 0.9 \\
\hline 5 & 86,110 & 5.0 & 4.5 & 1.1 & 385,547 & 6.2 & 1.2 \\
\hline 6 & 113,045 & 6.6 & 4.1 & 1.1 & 460,481 & 7.4 & 1.1 \\
\hline 7 & 151,472 & 8.8 & 4.8 & 1.5 & 731,081 & 11.7 & 1.3 \\
\hline 8 & 207,675 & 12.1 & 4.0 & 1.2 & 836,053 & 13.4 & 1.1 \\
\hline
\end{tabular}

1: Boreal to sub-boreal, 2: Atlantic, 3: sub-oceanic, 4: sub-continental (northern), 5: sub-continental (southern), 6: Mediterranean (semi-arid), 7: Mediterranean (temperate and sub-oceanic), 8: temperate mountainous. ${ }^{b}$ Expressed in terms of productivity index. ${ }^{c}$ Zone productivity factor $=\%$ of total productivity indices/\% of total area in the $E U(h=g / b)$.

cropland productivity of soils in the EU. However, a strong influence of soil type and soil properties was also verified.

Productivity showed a general trend of increasing in a northward and westward direction, however, local soil quality in most regions-except in the Mediterranean-can compensate for the climatic "handicap" to a great extent. While soils of the Atlantic region (CZ2), as was the case of the grassland ecosystem, have the highest relative potential to perform biomass provisioning ecosystem services in the cropland agro-ecosystem, this relative advantage is not as pronounced as in the case of grasslands (Table 6). In fact, soils of the northern sub-continental zone (CZ4; with $25.1 \%$ of the croplands of the EU) also perform above the EU average (zone productivity factor $=1.1$ ), and another four zones (CZ1, CZ3, CZ5, CZ8), with a total share of 31\% from the croplands of the EU, have, in general, soil productivity near the average of the continent (zone productivity factor $=1$; Table 6). Among these four zones, the suboceanic zone (CZ3) possesses the highest intra-variability, as indicated by the standard deviation of the productivity assessment. Cropland soils of the Mediterranean (CZ7 and CZ8) with a combined area share of $21.2 \%$ have substantially lower rain-fed crop productivity compared to the EU's average, demonstrated by zone productivity factors of 0.8 and 0.7 , respectively.

It is worth noting that irrigation can significantly increase the productivity of soils in the Mediterranean and to some extent also in the sub-continental region, where water is the limiting factor for crop growth. However, to assess (actual and potential) irrigated productivity of soil was out of 


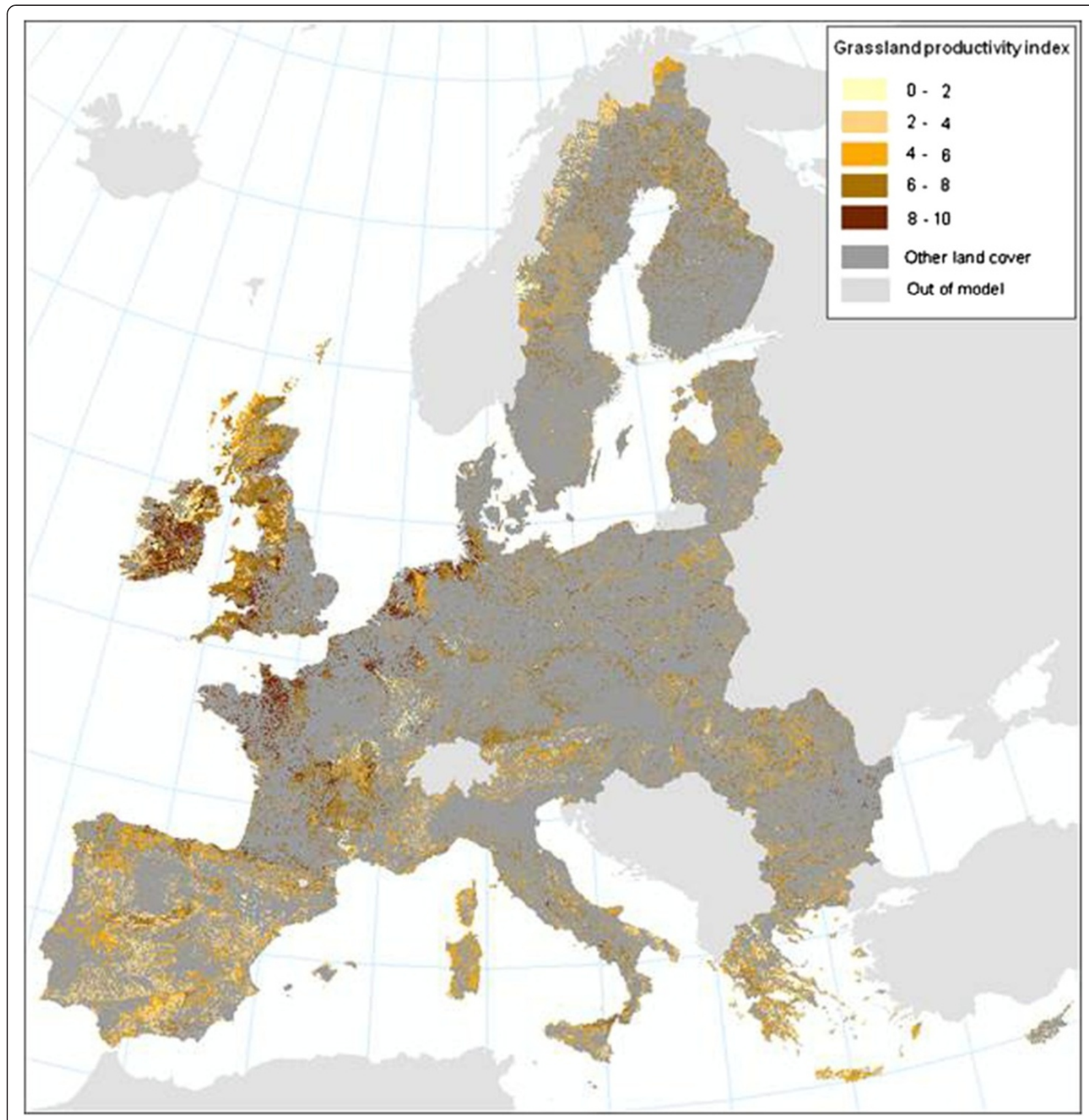

Figure 4 Soil biomass productivity of grasslands and pastures of the European Union.

the scope of this study. Nevertheless, future research should be carried out to analyze this aspect as well.

Results of soil productivity evaluation for croplands of the European Union are presented in Figure 5.

\section{Forest soil productivity map of the EU}

Forest productivity is essentially the expression of the interaction between climate and soil factors. The productivity of forest soils is a function of their ability to hold and make water available to trees (available water capacity,
AWC). Their nutrient status is also important. Available water capacity is a function of the rooting depth and texture of soils.

A common measure, especially in United States, for the evaluation of the collective influence of soil factors on forest growth is the site index (SI). The most important factors determining the SI are the topsoil depth and soil texture. The AWC parameter is strongly correlated with soil depth and soil texture and consequently can be used as a proxy of SI. 


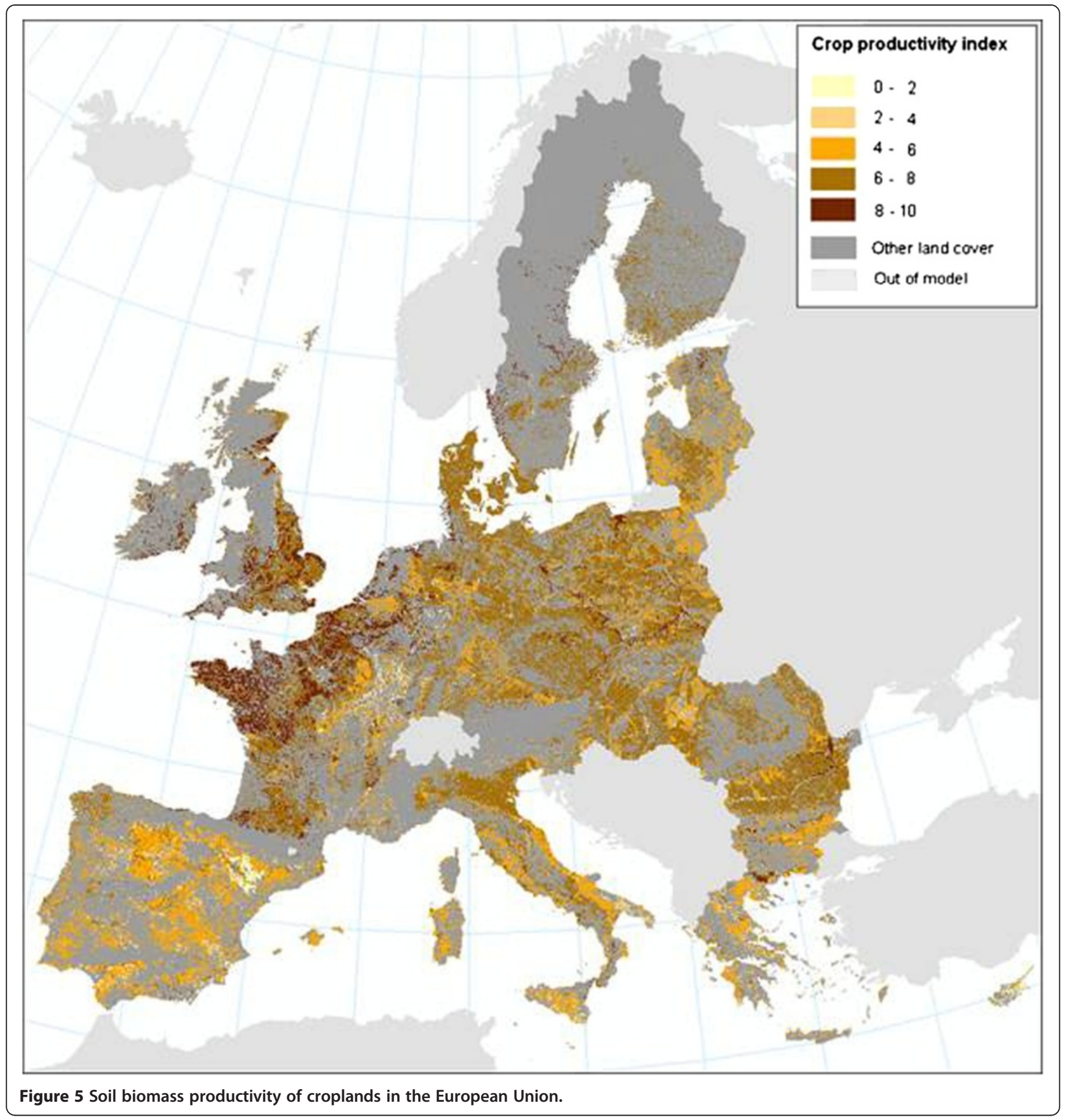

From the data shown in Figure 6, the climate driver is the most evident at larger scales, while the influence of soil can be detected mainly at more detailed scales. In fact, zone productivity factors (Table 6) have the widest range across the climate zones in Europe for forest land among the three land use classes assessed. The zone productivity factor is 1.4 for the Atlantic zone (CZ2), but only 0.6 for sub-boreal to boreal climates. In general terms, it is clear that climate is responsible for forest productivity variation at the regional scale while soil characteristics cause local (i.e., at scales of $10-100 \mathrm{~km}^{2}$ ) variations.

It is evident that in the northern areas the favorable moisture conditions are negated to some extent by the shorter length of the vegetative season, while in the Mediterranean climate the length of the vegetative season is not a constraint and water availability during summer represents the most important limiting factor.

The soil parameter taken into consideration in the proposed approach was the AWC, for which only three classes 


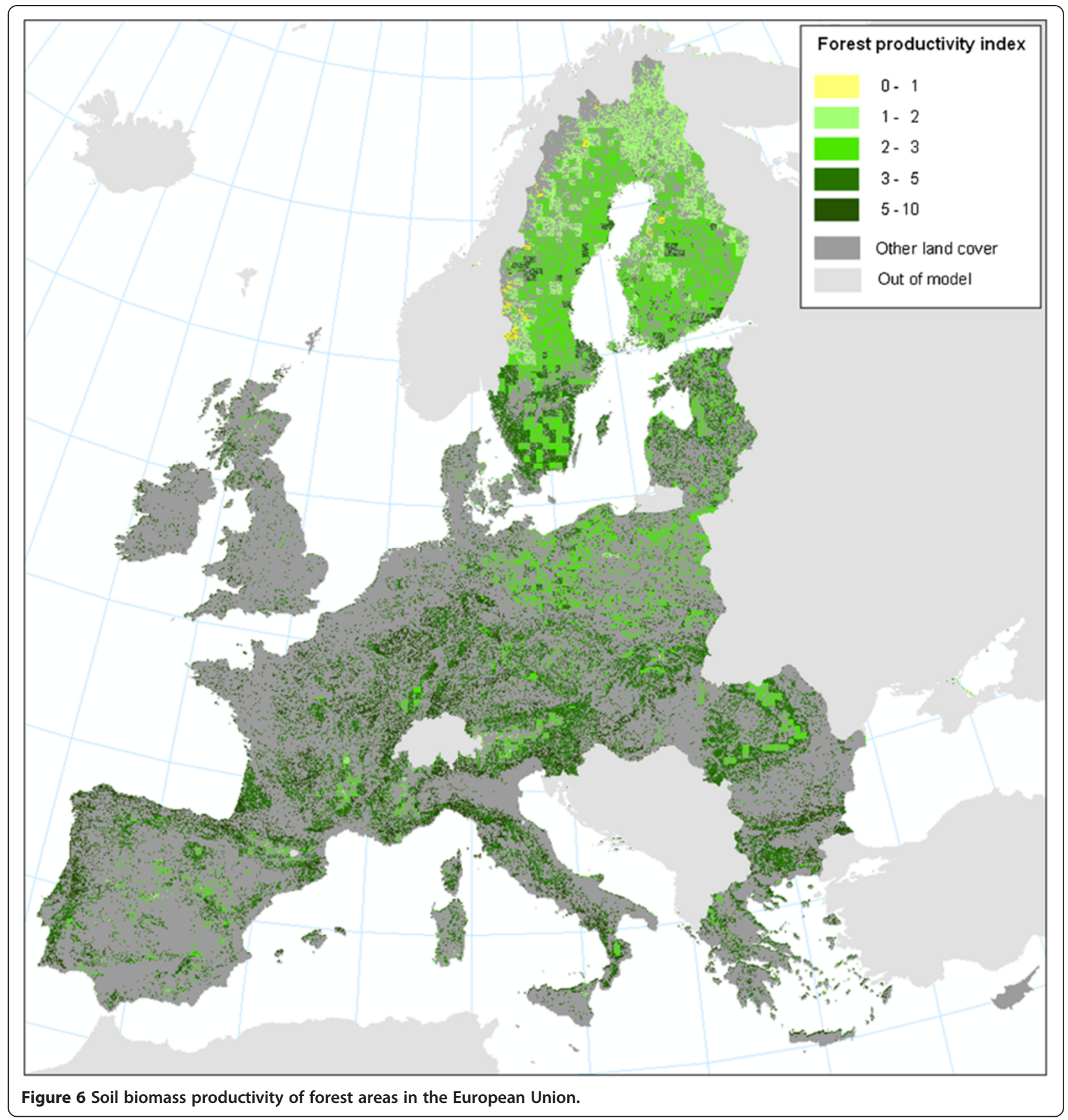

are available within the European Soil Geographic Database: 120,165 , and $220 \mathrm{~mm}$. The effect of soil is evident at a local scale, where it can result in a large variation in the absolute values of soil productivity.

\section{Continental-scale map of soil-extractable raw materials of the EU}

Raw material provisioning of the mapping units was calculated on the basis of the proportional shares of the STUs with raw material content in the area of each mapping unit. Once again it is important to stress that geological maps showing availability of materials worthwhile for human use that are present below the soil cover were not considered in this assessment and might show a very different pattern. The result of the assessment is presented in Figure 7.

It is well acknowledged that this first approximation to highlight the availability of soil-born raw materials on the continental scale might be biased (1) by the classification of soil materials of human interest for excavation and (2) by 

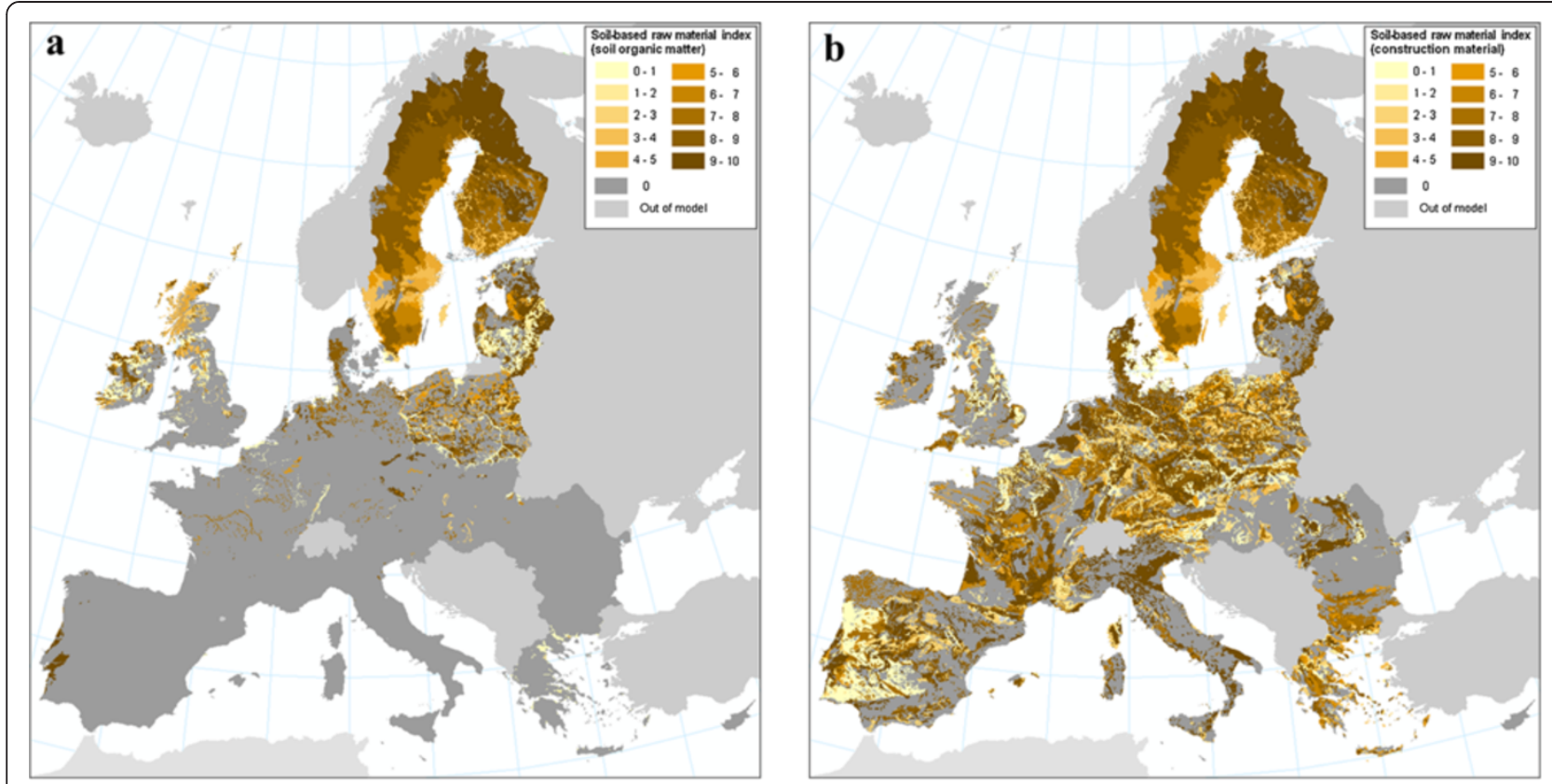

Figure 7 Raw material availability from soils of the European Union. a) organic soil material; b) soil material for constructions.

the thematic and geographic limitations of the dataset. However, the attempt to consider the main human activities that require materials of soil origin and to map the locations where those materials are available on a continental scale provides new insight to this field of research.

These maps showing a continental overview can suggest opportunities for raw material extraction from soil which can serve current or future needs for a number of applications, such as construction and the health industry (soil organic matter). The maps show that northern and north-eastern Europe have large stocks for both applications, while most other regions of the continent do not have large reserves of soil organic matter but are generally well suited for extraction of construction materials, with substantial intraregional differences.

The comparison of maps showing the raw material availability of European soils (Figure 7) and productivity of various land uses (Figures 4, 5, and 6) also proves the need for separate assessment of the components of soil quality. In general terms the geographic locations of the most suitable zones for agriculture and for procuring soil-borne materials are different. On the other hand, there are more overlaps between prime areas of forest lands and zones with potential to provide raw materials from soil. While the first assumption is positive for resource use planning, the second highlights the dilemma that land use planners usually face: the utilization of one service of the land might negatively influence another utilization option. With the evaluation of other soil functions and ecosystem services, the level of complexity for decision-making increases.

\section{Conclusions}

A coherent view of soils requires an expansion of the conventional thinking about the role of soils and consideration of soils in a multidimensional perspective in the context of sustainable development including the utilization of soilbased ecosystem services. Conscious utilization of soil ecosystem services can only be achieved on the basis of a proper accounting.

In this study, an assessment of soil functions in relation to ecosystem services was carried out for a continentalscale overview of the EU. A coherent system of soil function-based ecosystem services was devised, taking into account the major soil functions as identified in the Soil Thematic Strategy.

In this attempt to characterize soil ecosystem services for the EU in a spatially explicit manner, new data on soil-based provisioning ecosystem services were produced, including productivity and raw material availability. Results show that up to an average of $60 \%$ of grassland productivity differences can be attributed to climatic factors between the most favorable (Atlantic) and least favorable (semi-arid Mediterranean) regions of the EU. While crop productivity shows a general trend toward increasing in a northward and westward direction, local soil quality in most regions-except in the Mediterranean-can compensate for climatic handicaps to a great extent. The attempts to address the main human activities requiring materials of soil origin and to map the locations where those materials are available on a continental scale provide new insight to this field of research.

The comparison of areas with potential for providing ecosystem services by individual soil functions highlights 
the complexity of decision-making for resource utilization but also the possibilities for optimization and more conscious management.

With the evolution of time-series soil data based on monitoring, the increase in spatial precision of soil information, and the introduction of dynamic components to the models, comparative assessment of soil functions can be a valuable tool for decision-making in the future across geographical scales and for different stakeholder's needs.

\section{Endnotes}

${ }^{a}$ http://www.spot-vegetation.com/pages/VegetationProgramme/introduction.htm.

${ }^{\mathrm{b}}$ The Soil Atlas of Europe states: "Sand and gravel are the most accessible basic raw materials for the construction industry and are used as concrete aggregates, road base, mixed with bitumen for road surfaces, construction fill, snow and ice control (gritting), railroad ballast, roofing granules and water filtration systems."

\section{Competing interests}

The authors declare that they have no competing interests.

\section{Authors' contributions}

GT, CG, AJ, SJ, LM, and TP participated in the concept development. GT, CG, and $\mathrm{AJ}$ designed the models. KB and EA contributed to the GIS analysis. GT and Él designed and implemented the model validation. GT, AJ, CG, and SJ drafted the manuscript. All authors read and approved the final manuscript.

\section{Author's information}

Gergely Tóth is a senior scientist at the Joint Research Centre, Italy, where his key research themes include investigations of soil quality, soil degradation processes, geographical distribution of soil properties, and soil nutrient dynamics. He is vice chair of the Soil Evaluation and Land Use Planning Commission of the International Union of Soil Sciences.

Received: 6 September 2013 Accepted: 27 October 2013

Published: 25 November 2013

\section{References}

Aber JD, Ollinger SV, Driscoll CT (1997) Modelling nitrogen saturation in forest ecosystems in response to land use and atmospheric deposition. Ecol Model 101:61-78

Bicheron P, Leroy M, Brockmann C, Krämer U, Miras B, Huc M et al (2006) GLOBCOVER: a 300m global land cover product for 2005 using ENVISAT/ MERIS time series, Proceedings of the Recent Advances in Quantitative Remote Sensing Symposium, Valencia

Blum WEH (2005) Functions of soil for society and the environment. Rev Env Sci Biotechnol 4(3):p75-p79

Bouma E (2005) Development of comparable agro-climatic zones for the international exchange of data on the efficacy and crop safety of plant protection products. EPPO Bull 35:233-238

Brunsdon C, Fotheringham AS, Charlton M (1996) Geographically weighted regression: a method for exploring spatial nonstationarity. Geogr Anal 28:281-289

CEC (Commission of the European Communities) (2006) Communication from the Commission to the Council, the European Parliament, the European Economic and Social Committee and the Committee of the RegionsThematic strategy for soil protection, Commission of the European Communities. COM, Brussels, p 231

De Groot RS, Wilson MA, Boumans RMJ (2002) A typology for the classification, description and valuation of ecosystem functions, goods and services. Ecol Econ 41:393-408

EC (2003) European soil database (distribution version v2.0). European Commission Joint Research Centre, Ispra, Italy
EEA (2006) Land accounts for Europe 1990-2000. Towards integrated land and ecosystem accounting. EEA Report No 11/2006. EEA European Environmental Agency, Copenhagen

Eurostat (2011) NUTS—Nomenclature of territorial units for statistics. http:// epp.eurostat.ec.europa.eu/portal/page/portal/nuts_nomenclature/ introduction

Eurostat (2013) Agricultural statistics - Crops products. http://epp.eurostat.ec. europa.eu/portal/page/portal/agriculture/introduction

FAO (1976) A framework for land evaluation. FAO Soils Bulletin 32, Rome.

FAO/UNESCO/ISRIC (1990) Revised legend of the soil map of the world. World soil resources report. FAO, Rome

Fisher B, Turner RK, Morling P (2009) Defining and classifying ecosystem services for decision making. Ecol Econ 68:643-653

Fotheringham AS, Brunsdon C, Charlton M (2002) Geographically weighted regression: the analysis of spatially varying relationships. Wiley, Chichester

Hannam I, Boer B (2004) Drafting legislation for sustainable soils: a guide. IUCN, Gland

Hartwich R, Baritz R, Fuchs M, Krug D, Thiele S (2005) Erläuterungen zur Bodenregionenkarte der Europäischen Union and ihrer Nachbarstaaten 1:5,000,000 (version 2.0). Bundesanstalt für Geowissenschaften und Rohstoffe (BGR), Hannover

Haygarth PM, Ritz K (2009) The future of soils and land use in the UK: Soil systems for the provision of land-based ecosystem services. Land Use Pol 26 (suppl1):S187-S197

Hellden U, Tottrup C (2008) Regional desertification: a global synthesis. Glob Planet Change 64:169-176

JRC-EEA (2005) CORINE land cover updating for the year 2000: image 2000 and CLC2000. Products and methods. Report EUR 21757 EN. JRC, Ispra

Karlen DL, Andrews SS, Doran JW (2001) Soil quality: current concepts and applications. In: Sparks DL (ed) Advances in agronomy, 74. Academic, San Diego, pp 1-40

Köppen W (1936) Das geographische System der Klimate. In: Koppen W, Geiger R (eds) Handbuch der Klimatologie. IC, Berlin

Larson WE, Pierce FJ (1991) Conservation and enhancement of soil quality. In: Evaluation for Sustainable Land Management in the Developing World, Vol. 2: Technical papers. International Board for Research and Management. IBSRAM Proceedings No. 12 (2), Bangkok, Thailand, pp 75-203

MEA (Millennium Ecosystem Assessment) (2003) Ecosystems and human well-being: a framework for assessment. A report of the conceptual framework working group of the Millennium Ecosystem Assessment. Island Press, Washington DC

Panagos P, Van Liedekerke M, Filippi N, Montanarella L (2006) MEUSIS: towards a new multi-scale European soil information system. ECONGEO, 5th European Congress on Regional Geoscientific Cartography and Information Systems, Barcelona (Spain), pp 175-177

Parton WJ, Stewart JWB, Cole CV (1988) Dynamics of C, N, P and S in grassland soils: a model. Biogeochem 5:109-131

Peccol E, Movia A (2012) Evaluating land consumption and soil functions to inform spatial planning. 3rd International Congress on Degrowth for Ecological Sustainability and Social Equity, Venice (Italy), pp 19-23

Penman HL (1948) Natural evaporation from open water, bare soil and grass. Proc R Soc Series A 193:120-146

Rabus B, Eineder M, Roth A, Bamler R (2003) The shuttle radar topography mission-a new class of digital elevation models acquired by spaceborne radar. Photogramm Rem Sens 57:241-262

Raich JW, Rastetter EB, Melillo JM, Kicklighter DW, Steudler PA, Peterson BJ et al (1991) Potential net primary productivity in South America: application of a global model. Ecol Appl 1:399-429

Reid W, Mooney HA, Cropper A, Capistrano D, Carpenter SR, Chopra K et al (2005) Millenium Ecosystem Assessment synthesis report. Island Press, Washington DC

Robinson DA, Hockley N, Cooper DM, Emmett BA, Keith AM, Lebron I, Reynolds B, Tipping E, Tye AM, Watts CW, Whalley WR, Black HIJ, Warren GP, Robinson JS (2013) Natural capital and ecosystem services, developing an appropriate soils framework as a basis for valuation. Soil Biol Biochem 57:1023-1033

Running SW, Gower S (1991) FOREST-BGC, a general model of forest ecosystem processes for regional applications. II. Dynamic carbon allocation and nitrogen budgets. Tree Physiol 9:147-160

TEEB (2010) The Economics of Ecosystems and Biodiversity Ecological and Economic Foundations. In: Pushpam K (ed) Earthscan, London and Washington Chapter 5: the economics of valuing ecosystem services and biodiversity, http://www. 
teebweb.org/wp-content/uploads/2013/04/D0-Chapter-5-The-economics-ofvaluing-ecosystem-services-and-biodiversity.pdf (accessed on 14/11/2013)

Tóth G (2009) Land evaluation with the D-e-Meter system. Agrochem Soil Sci 58 (2):227-242

Van Liedekerke M, Panagos P, Montanarella L, Filippi N (2004) Towards a multi-scale european soil information system. 13th EC-GIS Symposium, Porto

doi:10.1186/2192-1709-2-32

Cite this article as: Tóth et al: Continental-scale assessment of provisioning soil functions in Europe. Ecological Processes 2013 2:32

Submit your manuscript to a SpringerOpen ${ }^{\circ}$ journal and benefit from:

- Convenient online submission

- Rigorous peer review

- Immediate publication on acceptance

- Open access: articles freely available online

- High visibility within the field

- Retaining the copyright to your article

Submit your next manuscript at $\boldsymbol{\nabla}$ springeropen.com 